\title{
Lichens, bryophytes and terrestrial algae of the Lake Untersee Oasis (Wohlthat Massiv, Dronning Maud Land, Antarctica)
}

\author{
Mikhail Andreev ${ }^{1 *}$, Dale Andersen ${ }^{2}$, Lyubov Kurbatova ${ }^{1}$, Svetlana \\ Smirnova ${ }^{1}$, Olga Chaplygina ${ }^{1}$ \\ ${ }^{1}$ Komarov Botanical Institute of the Russian Academy of Sciences, Professor Popov St. \\ 2, 197376 St. Petersburg, Russia \\ ${ }^{2}$ Carl Sagan Center, SETI Institute, 189 Bernardo Ave., Suite 100, Mountain View, \\ California 94043, USA
}

\begin{abstract}
Lake Untersee is the largest ice-covered freshwater lake in the interior of East Antarctica. The mountain oasis is situated around it in the Gruber Mts. of the Wohlthat Massif. For approximately 7,000 years the area has been free of ice and the local climate relatively stable. It is very severe, cold, and windy and dominated by intense evaporation and sublimation but with little melt. Relative humidity averages only $37 \%$. Vegetation is sparse in the oasis and previously only poorly investigated. Two lichen species and no bryophytes were known from the area. In November-December 2018, a survey of terrestrial flora and vegetation was made. The list of lichens was completed for the area, bryophytes were found for the first time, and some terrestrial algae were collected. In total, 23 lichen species, 1 lichenicolous fungus, 1 moss, and 18 terrestrial algae were discovered for the locality. The abundance of each species within their habitats was also evaluated. The lichen flora of the Untersee Oasis is typical for continental oases and similar to other previously investigated internal territories of Dronning Maud Land, except for the very rich lichen flora of the Schirmacher Oasis.
\end{abstract}

Key words: Queen Maud Land, Schirmacher Oasis, biodiversity, vegetation, flora, taxonomy, lichen biota, mosses

DOI: $10.5817 / \mathrm{CPR} 2020-2-16$

Received July 31, 2020, accepted December 2, 2020.

*Corresponding author: M. Andreev < andreevmp@yandex.ru>

Acknowledgements: Primary support for research was provided by the Tawani Foundation of Chicago, the Trottier Family Foundation, NASA's Exobiology and Astrobiology Programs, Arctic and Antarctic Research Institute/Russian Antarctic Expedition's Subprogram "Study and Research of the Antarctic" of the Federal Target Program "World Ocean.", partly by the Russian Foundation of Fundamental Sciences (18-04-00900, 19-54-18003), and by the research project of the Komarov Botanical Institute RAS (AAAA-A18-118022090078-2). Logistics support was provided by Antarctic Logistics Centre International (ALCI), Cape Town, South Africa. Microphotographs of algae were taken using equipment of the Core Facility Center "Cell and Molecular Technologies in Plant Science" at the Komarov Botanical Institute of the Russian Academy of Sciences (St. Petersburg, Russia). In particular we thank reviewer Ole William Purvis (Natural History Museum, London) for his constructive comments and suggestions on earlier version of this manuscript. 


\section{Introduction}

Wohlthat Massif is situated in the central part of Dronning Maud Land (Queen Maud Land) between $11^{\circ} \mathrm{E}$ and $14^{\circ} \mathrm{E}$ and ca. $200 \mathrm{~km}$ south of the barrier of Novolazarevskaya Ice Shelf. It consists of the Humboldt Mts., several North-South facing ridges of the Petermann Ranges and the generally East-West facing Gruber Mts.
(Otto-von-Gruber-Gebirge). The Untersee Oasis (Fig. 1) with two ice covered lakes Untersee and Obersee, is situated in the alpine high mountain region of Gruber Mts. It covers an area ca $15 \mathrm{~km}$ lying eastwest and 20-25 km towards the northsouth (Haendel and Kaup 1986).

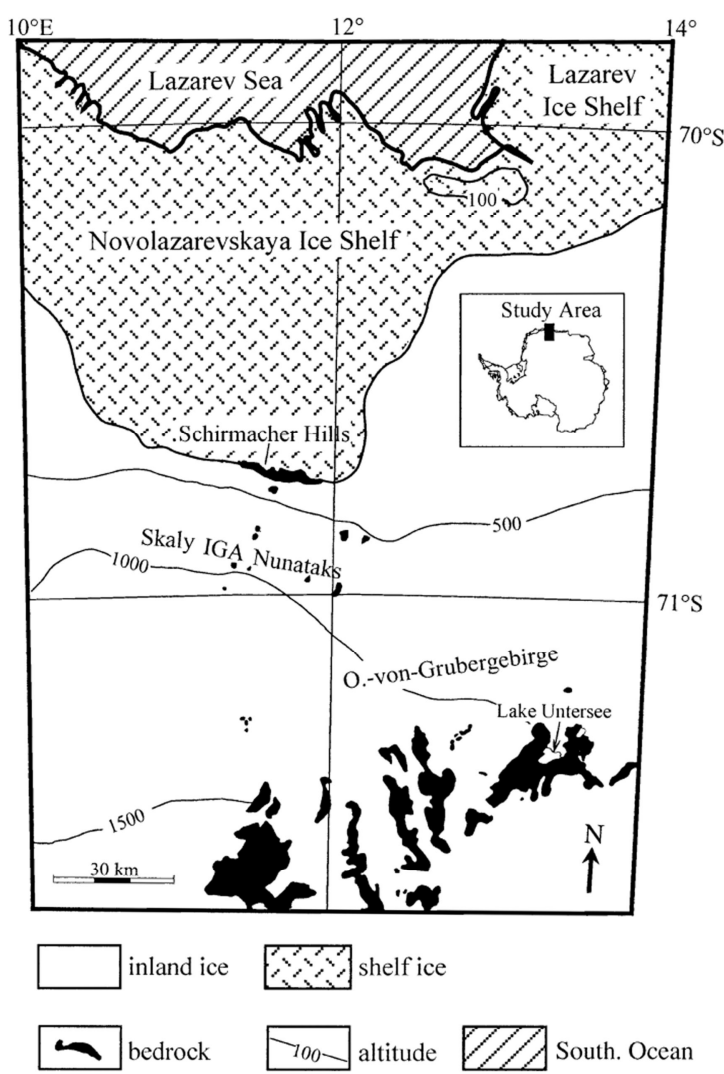

Fig. 1. Sketch map of the study area with the location of Lake Untersee, central Dronning Maud Land, East Antarctica. Altitude is given in meters above sea level (Wand et al. 1997).

Lake Untersee is located at $71^{\circ} 20^{\prime} \mathrm{S}$ and $13^{\circ} 45^{\prime} \mathrm{E}$ at an altitude of $563 \mathrm{~m}$ a. s. 1 . and covers a surface area of $11.4 \mathrm{~km}^{2}$ (6.5 km long and $2.5 \mathrm{~km}$ wide) (Fig. 2, 3). It is one of the largest and deepest $(>160 \mathrm{~m}$ deep) perennially ice-covered ultraoligotrophic freshwater lakes in continental Antarctica (Hermichen et al. 1985, Andersen et al. 2011). The lake arose from a meltwater pond during climatic optimum periods in the Holocene. Ice cover has ranged in thickness from 2.2 to $3.8 \mathrm{~m}$ over time. Lake Obersee $\left(3.43 \mathrm{~km}^{2}\right)$, located $7 \mathrm{~km}$ north-eastern of the lake Untersee, is comparatively shallow with a depth less than $20 \mathrm{~m}$. 


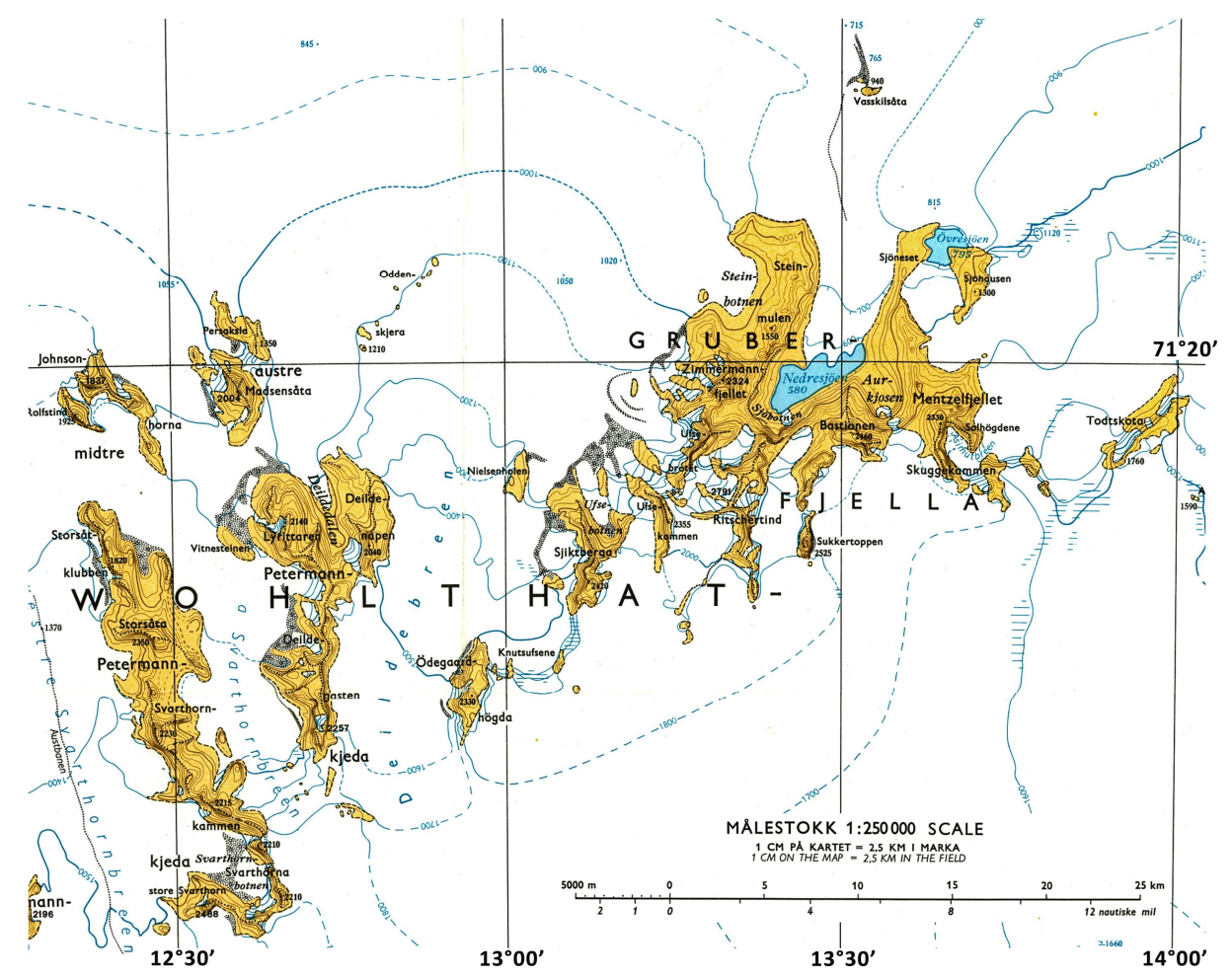

Fig. 2. Wohlthat Massiv, Gruber Mountains and Lake Untersee Oasis (Dronning Maud Land, East Antarctica).([1]-Map Wohlthatmassivet, Fimbulheimen, Sheet M5. Norsk Polarinstitutt, Oslo, 1968).

Lake Untersee lies in the basin of a deep cirque-like glacial trough valley which is open to the North and surrounded on its eastern, southern, and western sides by the high Gruber Mts. (central Wohlthat Massif). The southern main crest reaches nearly $3,000 \mathrm{~m}$ a. s. 1. (Ritscher Peak $2,810 \mathrm{~m}$ ). The mean elevation of the polar plateau around the lake is ca. $1,000 \mathrm{~m}$. Steep, partly moraine-covered mountain slopes (up to $300-400 \mathrm{~m}$ high from the present lake's level) surround the remaining sides of the lake (Simonov et al. 1985).

The cirque of Lake Untersee was formed around 58,000 yr BP, as a result of deep ice scouring (Stackebrandt 1995). The last ice retreat began between 12,000 and $10,000 \mathrm{yr}$ BP. The present geomorphological situation has existed for approximately
7,000 years (Simonov et al. 1985). Since that time, the area has been free of ice and the climate relatively stable.

The mean annual temperature at Lake Untersee was determined to be $-10.6^{\circ} \pm$ $0.6^{\circ} \mathrm{C}$. The average wind speed recorded was $5.4 \mathrm{~m} \cdot \mathrm{s}^{-1}$ and maximum $35.7 \mathrm{~m} \cdot \mathrm{s}^{-1}$. Strong winds are associated with katabatic flows from the south. The dominant wind direction for strong winds is from the south during all seasons, with a secondary source in the summer from the East-Northeast. Relative humidity averages at $37 \%$. Low summer temperatures and high wind speeds create conditions resulting in a local climate that is dominated by intense evaporation and sublimation but with little melt (Andersen et al. 2015). 


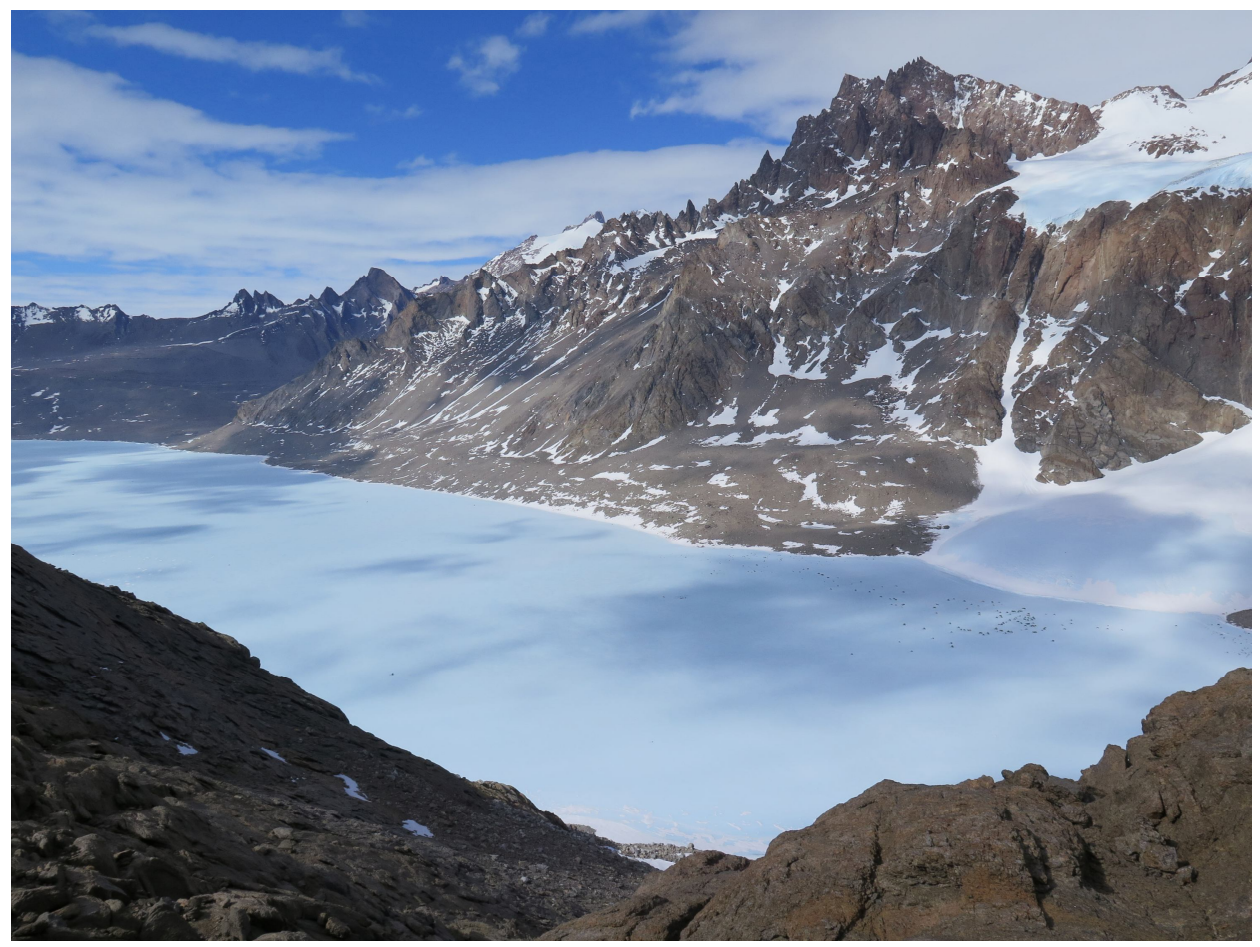

Fig. 3. Lake Untesee and Mt. Bastei. View towards NEE into the Untesee depression. (Photo: M. Andreev).

The area of the northeastern part of central Dronning Maud Land including the Schirmacher Oasis, Wohlthat Massif and other inland mountain ridges, was first investigated and mapped in 1939 from the air by pilots of the German Antarctic Expedition (Bormann and Fritzsche 1995).

In 1949-1952 the British Swedish Norwegian Antarctic expedition and later in 1958-1959 Norwegian Antarctic Expedition were undertaken in the western part of Dronning Maud Land. The main regular observations and the first systematic geographical and geological investigations of the region, including the Wohlthat Massif, were carried out by the $4^{\text {th }}-6^{\text {th }}$ Soviet Antarctic Expeditions ([2] - Atlas Antarktiki 1969, Bormann and Fritzsche 1995).

The first botanical specimens were collected in the 1950-60's during expeditions in the western part of Dronning Maud Land (Bowra et al. 1966, Lindsay 1971, 1972; Lindsay and Brook 1971, Ryan et al. 1989, Thor 1995), and in Sør Rondane in the eastern part (Dodge 1962). Contemporary the first botanical collections from Dronning Maud Land were obtained by the Komarov Botanical Institute (St. Petersburg, Russia). N. S. Golubkova studied lichens from the Schirmacher Oasis, collected by I. M. Simonov in 1962-1963 and 1965-1966 (Golubkova and Savicz 1965, 1966; Golubkova and Simonov 1972). One newly described moss species from the Schirmacher Oasis was reported by Savicz-Lyubitskaya and Smirnova (1964). The other authors (Aleshinskaya and Bardin 1965) reported varieties of algae determined in water samples taken from lakes of the Schirmacher Oasis. 
Lake Untersee Oasis has repeatedly attracted scientific interest during recent years (Kaup et al. 1988, Richter and Bormann 1995), but because of its remote location it has received much less attention than other areas in this part of the Antarctic continent. In January/February 1969, the first traverse to the Untersee Oasis area was made by the $14^{\text {th }}$ Soviet Antarctic Expedition team and the first geographicgeological and hydrological study of the area was made (Kosenko and Kolobov 1970). The joint Soviet-German team led by I. M. Simonov investigated the area in 1983 (Klokov et al. 1987) and carried out limnological, paleoenvironmental and geological studies of the Wohlthat Massif (Kaup et al. 1988). During the 1970-90's, German scientists studied the Schirmacher and the Untersee Oases areas. The latter one was just briefly investigated. They carryied out floristic studies of algae, lichens and bryophytes. Since 1983, geologists of the former German Democratic Republic have made three expeditions to the region, the first of which was a joint SovietGerman activity. Every summer for more than 10 years, Dale Andersen has organized and conducted different investigations of the lake and the surrounding area within the framework of NASA's Exobiology and Astrobiology Program (Andersen et al. 2011, 2015).

Dronning Maud Land has been little explored botanically except for the Schirmacher Oasis. In 1966 a few results from the early biological studies have been first summarized (Bowra et al. 1966). In that time only a restricted number of lichens, a few algae and two mosses from a few collections from Tottanfjella and Heimefrontfjella in the western part of Dronning Maud Land were discovered (Lindsay 1971). The list of 13 lichen species was published by D. C. Lindsay (1972) on the base of the collection made by Norwegian geologists in Vestfjella in 1968-1969. Lichens from that area were later studied by Øvstedal (1983b). The lichen and moss collections by G. T. Bowra in Heimefrontfjella in 1963-1964 were redetermined by G. Thor, who has studied the materials of the Swedish expedition of 1991-1992 as well. In total, 16 lichen and two moss species were found (Thor 1995). Lichens of Sverdrup Mountains were studied by Øvstedal (1983a) on the basis of specimens collected by J. Angard during the Norwegian Antarctic Expedition (19701971). Lichens collected during the BritishSwedish-Norwegian Antarctic Expedition to the internal areas of Dronning Maud Land in 1949-1952 were studied by Øvstedal (1986) and 23 species recorded. Biological survey of the Robertskollen nunataks was undertaken by the South African Antarctic Expedition during the summer of 1987-1988 (Ryan et al. 1989). Provisional classification of plant communities in the Gjelsvikfjella and Mühlig-Hofmannfjella Mts. was proposed by Engelskjøn (1985, 1986).

In the eastern part of Dronning Maud Land, Dodge (1962) recorded 10 lichen species from Sør Rondane mountains ca. $400 \mathrm{~km}$ south-east from the Untersee Oasis. In 1989 and 1990, Japanese biologists worked in the Sør Rondane Mountains (Ohyama et al. 1991). Recently, Utsteinen Nunatak in this area has been studied lichenologicaly. A detailed study of the lichen vegetation was performed for the Utsteinen Ridge chosen for construction of the Belgian Antarctic station "Princess Elisabeth" (Ertz et al. 2014).

The nearest place already studied botanically in this region is the Schirmacher Oasis $\left(70^{\circ} 44^{\prime}-70^{\circ} 46^{\prime} \mathrm{S}\right.$ and $11^{\circ} 20^{\prime}-$ $11^{\circ} 55^{\prime}$ E) lying ca. $90 \mathrm{~km}$ to the northwest from the Lake Untersee Oasis. Lichens from the Schirmacher Oasis were collected for the first time in 1962-63 and 1965-66 by a Soviet wintering member I. M. Simonov. N. S. Golubkova identified 21 lichen species and one moss in this collection (Savicz-Lyubitskaya and Smirnova 1964, Golubkova and Savicz 1965, 1966; Golubkova and Simonov 1972). 
In 1979-1980 a member of the East German Antarctic team W. Richter collected in the Schirmacher Oasis and on adjacent nunataks (Huneck and Richter 1982, Richter 1985, 1986, 1990). He has compiled information published by German and Russian researchers and totally reported 26 lichen species (Richter 1995). Indian lichenologists D. K. Upreti (Upreti 1996, 1997; Pandey and Upreti 2000) and S. Nayaka (Nayaka and Upreti 2005, 2008; Nayaka et al. 2009) and others (Gupta et al. 1999) listed 48 lichen species. Subsequently, Olech and Singh (2010) mentioned 57 lichen species. M. Andreev has studied the lichens of the Schirmacher

\section{Material and Methods}

The area of the Untersee Oasis was visited by two of the authors in 2018 from 2 November to 14 December. A detailed study of the lichen flora and vegetation was made, including the lower slopes of the Untersee Lake's depression, Sjøbotnen and Aurkjøsen cirques, the slopes of Steinmulen Shoulder, Mirazh Mt., Zimmermann Mt., Bastei Mt., and Mentzel Mt., Sjøneset Spur and Seekopf Mt. near Lake Obersee (Fig. 4).

The material collected in the Lake Untersee Oasis is scant, and samples generally tiny. Rather extensive areas proved to be lifeless in respect of lichens and mosses presence. No lichens were found and collected on the lake's bank, moraines, and gravel screes. Most samples were collected in sheltered places on stable rocks, mainly near melting snow, ca. $50 \%$ of samples at an altitude between $750-1000 \mathrm{~m}$ a. s. 1 , ca. $20 \%$ between $1000-1300 \mathrm{~m}$ a. s. 1 . The highest collecting point was at about
Oasis from 2004 to 2019. 75 lichen species have been collected in the oasis (Andreev, unpubl.). In our opinion the local lichen flora of the Schirmacher Oasis in the current state is the richest in the continental Antarctic, probably except of some areas of the Antarctic Peninsula.

The first general observations on the moss flora of the Schirmacher Oasis were made by Richter (1995) and 7 species of mosses recorded. The same species were accepted by the Indian bryologist Lal (2004). Later, the list of mosses was extended to include 12 species (Ochyra and Singh 2008, Kurbatova and Ochyra 2012).

$1365 \mathrm{~m}$ a. s. 1. Habitats at higher altitudes were rather inaccessible because of remoteness, extremely steep slopes, or the risk of avalanches. About 140 specimens in 34 sites were collected. All specimens cited here are preserved in the Herbarium of the Komarov Botanical Institute in St. Petersburg, Russia (LE).

Identification of green algae (Chlorophyta) and some Cyanoprokaryota forming crusts on stones and sand (collecting sites. Untersee: 191705, 192111, 192601) was carried out using cultural methods (Brown and Bold 1964). Identification of algae was performed using Carl Zeiss light microscopes with apochromatic (40/ $095 ; 100 / 1.25)$ and planachromatic (40/065; 100/1.25) lenses. Microphotographs were taken using a Zeiss AxioImager A1 light microscope with Nomarsky contrast and the AxioCamMRc5 image documentation system. 


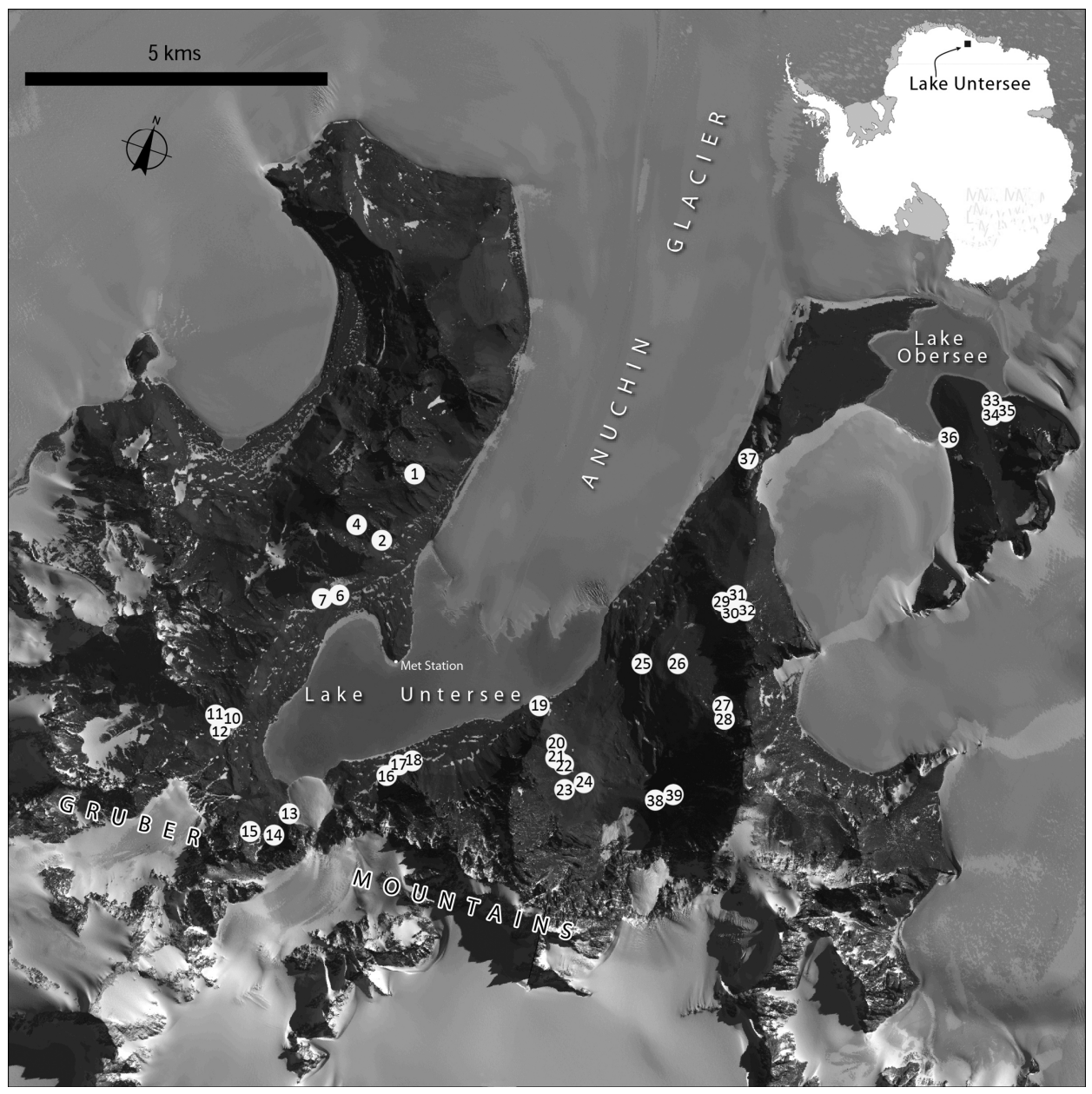

Fig. 4. Collecting sites in Lake Untersee Oasis. Untersee depression: 1, 2, 4, 6, 7, 10-23, 25-32, 38, 39; Obersee vicinity: 33-37. (Photo: Andersen et al. 2015).

\section{List of localities}

All localities: Antarctica, Dronning Maud Land (see below as DML), Neu Schwabenland, Wohlthat Massiv, Gruber Mts. (Otto-von-Gruber Gebirge), the Untersee Oasis. Col. M. Andreev. Det. M. Andreev (lichens), L. Kurbatova (mosses), S. Smirnova and O. Chaplygina (algae). Untersee and Obersee - two collecting areas in the Lake Untersee Oasis. Localities 3, 5, 8, 9, 24 absent in the list because no botanical specimens were found there.

a) Untersee:

1. Lake Untersee, Steinmulen Shoulder, Mirazh Mt. to the N from the lake, snow petrel's valley, eastern slope, dark rocks, in crevice. S $71^{\circ} 18.501, \mathrm{E} 13^{\circ} 27.019$, alt. $917 \mathrm{~m}$. 14.12.2018.

2. ibid, eastern slope, reddish rocks, in crevice. S $71^{\circ} 19.206, \mathrm{E} 13^{\circ} 26.461$, alt. $789 \mathrm{~m}$. 22.11.2018. 
4. ibid, eastern slope, flat exposed rock in the slope's upper part, in crevice. S $71^{\circ} 19.115$, E $13^{\circ} 25.804$, alt. $1046 \mathrm{~m}$. 22.11.2018.

6. ibid, eastern slope, scree under rock. S $71^{\circ} 19.753$, E $13^{\circ} 25.579$, alt. $781 \mathrm{~m}$. 26.11.2018.

7. ibid, eastern slope, crevice in the foot of cliff. S $71^{\circ} 19.837$, E $13^{\circ} 25.297$, alt. $757 \mathrm{~m}$. 26.11.2018.

10. Lake Untersee, western bank at the foot of Zimmermann Mt., small ridge of lightcolored rocks, stretching down the slope. S 71²1.164, E $13^{\circ} 23.049$, alt. $922 \mathrm{~m}$. 27.11.2018.

11. ibid, top of small ridge of light-colored rocks, stretching down the slope, flat place with snow bed. S $71^{\circ} 21.149$, E $13^{\circ} 22.956$, alt. 979 m. 27.11.2018.

12. ibid, vertical rocks, near the foot. $\mathrm{S} 71^{\circ} 21.266$, E $13^{\circ} 22.850$, alt. $979 \mathrm{~m}$. 27.11.2018.

13. Lake Untersee, southern bank, cirque near the foot of Ritscher Peak, moraine with big boulders near small glacier, in crevice on boulder. S $71^{\circ} 21.991$, E $13^{\circ} 25.231$, alt. 679 m. 28.11.2018.

14. ibid, cirque with vertical walls near small glacier, big boulders and sand in central part. S $71^{\circ} 22.205$, E $13^{\circ} 24.910$, alt. 869 m. 28.11.2018.

15. ibid, cirque with vertical walls near small glacier, rocks in eastern side, in rock crevice. S $71^{\circ} 22.202$, E $13^{\circ} 24.294$, alt. 946 m. 28.11.2018.

16. Lake Untersee, south-eastern bank neat Mt. Bastei, vertical rock over moraine, in crevices. S $71^{\circ} 21.495, \mathrm{E} 13^{\circ} 27.674$, alt. $759 \mathrm{~m} .29 .11 .2018$.

17. ibid, vertical rock over moraine, in crevices. S $71^{\circ} 21.446$, E $13^{\circ} 27.743$, alt. $751 \mathrm{~m}$. 29.11.2018.

18. ibid, vertical granite rock over moraine near pinkish rock, in crevices. $\mathrm{S} 71^{\circ} 21.373$, E $13^{\circ} 28.218$, alt. 770 m. 29.11.2018.

19. Lake Untersee, northern spur of Mt. Bastei at southern side of entrance to the Aurkjøsen Cirque, hollow under rock with big boulders and sand near snow petrel's nest. S $71^{\circ} 20.660$, E $13^{\circ} 31.506$, alt. 688 m. 30.11.2018.

20. Lake Untersee, Aurkjøsen Cirque east of the lake, northern spur of Mt. Bastei, northeastern slope, big boulders on moraine under rocks. S $71^{\circ} 21.103$, E $13^{\circ} 32.277$, alt. $811 \mathrm{~m} .01 .12 .2018$.

21. ibid, north-eastern slope, rocks lower down, sheltered from cold winds from glacier, near snow bed. S $71^{\circ} 21.188$, E $13^{\circ} 32.148$, alt. 917 m. 01.12.2018.

22. ibid, north-eastern slope, rock sheltered from winds from glacier, near snow bed. $\mathrm{S} 71^{\circ} 21.250, \mathrm{E} 13^{\circ} 32.272$, alt. $913 \mathrm{~m} .01 .12 .2018$.

23. ibid, north-eastern slope, at the foot of vertical rock near cornice glacier. $\mathrm{S} 71^{\circ} 21.480, \mathrm{E} 13^{\circ} 32.604$, alt. $963 \mathrm{~m} .01 .12 .2018$.

25. Lake Untersee, Aurkjøsen Cirque east of the lake, northern spur of Mt. Mentzel, south-western slope, series of terraces, big boulders on terrace. S $71^{\circ} 20.154$, E $13^{\circ} 34.128$, alt. 887 m. 02.12.2018.

26. ibid, northern spur of Mt. Mentzel, south-western slope, series of terraces, big boulders on terrace, sheltered place with snow under a boulder, near a nest. $\mathrm{S} 71^{\circ} 20.131, \mathrm{E} 13^{\circ} 35.136$, alt. $1034 \mathrm{~m}$. 02.12.2018.

27. ibid, northern spur of Mt. Mentzel, south-western slope, series of terraces, big boulders on terrace under rock. S 71 20.490 , E 1336.461, alt. $1229 \mathrm{~m}$. 02.12.2018.

28. ibid, a top of the northern spur of Mt. Mentzel, rock facing north-east, near snow bed. S $71^{\circ} 20.539$, E $13^{\circ} 36.562$, alt. $1255 \mathrm{~m}$. 02.12.2018.

29. ibid, northern spur of Mt. Mentzel, south-western slope, big boulders on the slope, niche in boulder facing north. S $71^{\circ} 19.522$, E 13³6.018, alt. 1252 m. 03.12.2018. 
30. ibid, northern spur of Mt. Mentzel, south-western slope, big boulders on the slope, niche in boulder facing north. S 71 ${ }^{\circ} 19.514$, E 13³6.079, alt. 1268 m. 03.12.2018.

31. Lake Untersee, top of the northern spur of Mt. Mentzel, saddle, north-eastern slope. $\mathrm{S} 71^{\circ} 19.487, \mathrm{E} 13^{\circ} 36.325$, alt. $1364 \mathrm{~m}$. 03.12.2018.

32. Lake Untersee, Aurkjøsen Cirque east of the lake, northern spur of Mt. Mentzel, south-western slope, scree under rock, beneath boulder near a nest and snow bed. $\mathrm{S} 71^{\circ} 19.496, \mathrm{E} 13^{\circ} 36.272$, alt. 1365 m. 03.12.2018.

38. ibid, Mt. Mentzel, north-western slope under glacier, fissure in rock. S $71^{\circ} 21.495$, E $13^{\circ} 35.270$, alt. $660 \mathrm{~m} .09 .12 .2018$.

39. ibid, Mt. Mentzel, south-western slope under vertical wall, fissure in rock. $\mathrm{S} 71^{\circ} 21.395$, E $13^{\circ} 35.501$, alt. 754 m. 09.12.2018.

b) Obersee:

33. Lake Obersee, Mt. Seekopf to the E from the Lake Obersee, northern slope, in deep crevice with sand, under snow bed. S $71^{\circ} 17.238$, E $13^{\circ} 42.602$, alt. $1019 \mathrm{~m}$. 04.12.2018.

34. ibid, vertical crevice in rock. $\mathrm{S} 71^{\circ} 17.276$, E $13^{\circ} 42.663$, alt. $1072 \mathrm{~m}$. 04.12.2018.

35. ibid, a top of spur, in crevice. S $71^{\circ} 17.278$, E $13^{\circ} 42.479$, alt. $1056 \mathrm{~m}$. 04.12.2018.

36. ibid, flat rock, streams from snow bed. S $71^{\circ} 17.618$, E $13^{\circ} 41.317$, alt. $941 \mathrm{~m}$. 04.12.2018.

37. Lake Obersee, Sjøneset Spur between Anuchin Glacier and the Lake Obersee, flat hill, flat rock on the top facing $\mathrm{N}$, in crevice. S $71^{\circ} 18.002$, E $13^{\circ} 35.689$, alt. $913 \mathrm{~m}$. 08.12.2018.

\section{Results and Discussion}

In total, 23 lichen species, 1 lichenicolous fungus, 1 moss, and 18 terrestrial algae species were discovered following the investigation of the field material sampled from the Lake Untersee Oasis. All lichen species are new for the area apart from two lichens: Umbilicaria aprina and Rusavskia elegans mentioned previously (Richter 1995).

The most common lichens recorded in the Lake Untersee Oasis are within the families Teloschistaceae, Physciaceae, Acarosporaceae and Lecanoraceae (about $80 \%$ specimens) and within the genera Acarospora, Buellia and Rusavskia (about $50 \%$ specim.). The most common and conspicuous lichens are Rusavskia elegans, Acarospora gwynnii and Buellia frigida (56 specimens). Rather common are Candelariella flava, Amandinea petermannii, Caloplaca citrina, Lecidea andersonii and Lecanora expectans (35 specimens). As a result, more than half $(65 \%)$ of all lichens sampled belong to the 8 above-listed species. These eight lichens play distinct role in the vegetation of the Lake Untersee Oasis forming overwhelming majority of cryptogamic communities.

The lichen flora in the Lake Untersee Oasis is dominated by crustose lichens represented by 17 species. Foliose lichens in the area are represented by seven species of the genera Amandinea (1), Physcia (2), Umbilicaria (2), Xanthomendoza (1), Rusavskia (1). Most lichens (75\%) are saxicolous species. Approximately $25 \%$ - are terricolous or muscicolous. Some of these also occur on rocks. One species - Endococcus propinquus, is lichenicolous and parasitic on Rusavskia elegans. Slightly more than a half of the recorded lichens (13 species) are Antarctic endemics. 11 species are cosmopolitan, bipolar lichens, frequent throughout the Northern hemisphere. 
All species have a circumpolar distribution.

Lichens in the oasis were more abundant on northern slopes in sheltered places near melting snowfields, along rock crevices and on gravel under boulders, whereas more exposed rocky surfaces are almost devoid of lichens. Lichens were also poorly represented in other ice and snow free areas, like moraines and screes. In all cases, the lichens occured in very low quantities in the area. Moreover, all specimens were tiny.

The lichen diversity of the Lake Untersee Oasis is similar to a number of other mountain groups investigated in Dronning Maud Land (Vestfjella: Lindsay 1972; Heimefrontfjella: Thor 1995; Utsteinen Nunatak: Ertz et al. 2014), where the number of species varies between 16 and 35 , and is typical for the continental Antarctic, except for the very rich lichen flora of the Schirmacher Oasis.

Bryophytes were found for the first time in the Lake Untersee Oasis. Only one species - the Antarctic endemic moss Syntrichia sacroneurum - was discovered. Specimens were collected in four sites only. Mosses occur rarely and only in extremely protected habitats influenced by meltwater. Syntrichia sacroneurum [along with another Antarctic endemic moss Coscnodon lawianus (J. Y. Willis) Ochyra] is one of the most common mosses of mountain ranges and nunataks in Dronning Maud Land.

Black crusts on sand and stones, col- lected at the site 36 (Fig. 4) near the lake Obersee was formed by Cyanoprokaryotes. Microscopic study revealed that it mainly consists of bunches of Calothrix or Hassallia. These species were mainly accompanied by Asterocapsa spp. in sample 193601 and Gloeocapsa spp. and filamentous species in sample 193602. Collecting sites 17, 21 and 26 were dominated by green algae, but Cyanoprokaryotes (Chroococcidiopsis and Phormidesmis priestly) were also found in culture in the sample 192111.

Altogether, 14 species of Cyanoprokaryota were found belonging to 3 subclasses: Oscillatoriophycidae (order Chroococcales, families Entophysalidaceae and Microcystaceae; order Chroococcidiales, family Chroococcidiopsidaceae; order Oscillatoriales, family Coleofasciculaceae), Synechococcophycidae (order Synechococcales, family Leptolyngbyaceae) and Nostocophycidae (order Nostocales, families Rivulariaceae and Tolypothrichaceae).

Green algae (Chlorophyta) detected in fouling on stones and sand, are representatives of the class Trebouxiophyceae and belong to two orders-Prasiolales (Prasiola crispa, Prasionella wendyae, Stichococcus bacilaris) and Trebouxiales (Trebouxia $\mathrm{cf}$. arboricola). Prasionella wendyae is reported for the first time for the Antarctic region. This is a new species identified on basalt rock just above tidal zone of the Svalbard Archipelago (Norway) (Heesch et al. 2016).

\section{Annotated checklist of lichens, bryophytes, and algae in the Lake Untersee Oasis}

\section{Lichens}

Acarospora gwynnii C. W. Dodge \& E. D. Rudolph (1955). - (Syn.: A. petalina N. S. Golubk. \& Savicz). In rock fissures and on consolidated debris in very exposed situations at an altitude $680-1270 \mathrm{~m}$ a. s. 1., in habitats influenced by meltwater. Saxicolous. Antarctic endemic. Widespread and common in continental Antarctic. Reported many times and widely distributed throughout DML (Schirmacher Oasis and internal areas). Most common lichen in the area. Collecting sites: Untersee - 1, 2, 4, 10, 11, 12, 13, 14, 20, 22, 25, 30; Obersee-33, 34, 35, 37. Fig. 5A, B. 

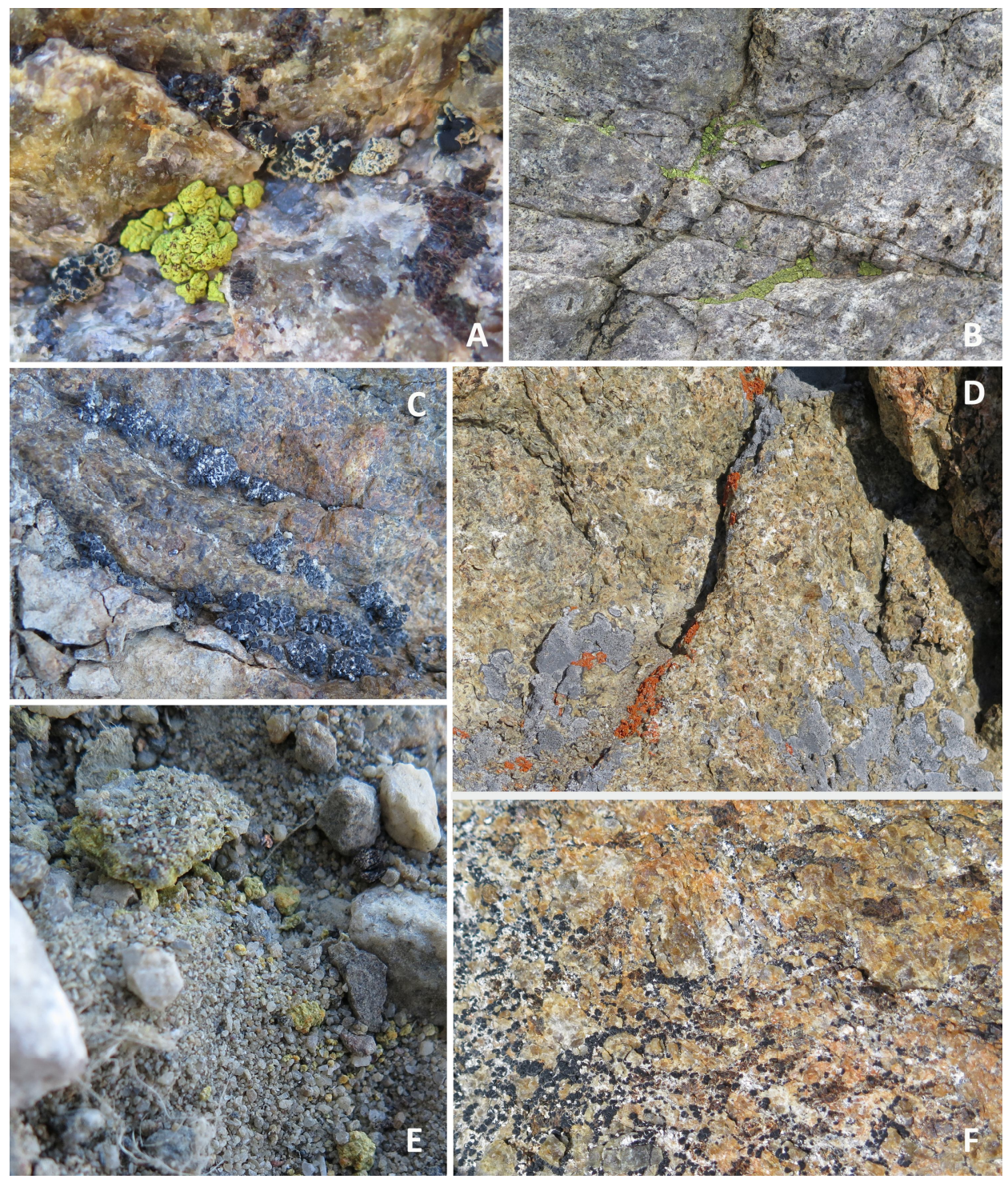

Fig. 5. Lichens of the Lake Untersee Oasis. A - Acarospora gwynnii \& Rhizoplaca melanophthalma; B - Acarospora gwynnii; C - Amandinea petermannii; D - Buellia frgida \& Rusavskia elegans; E - Candelariella flava; F - Lecidea andersonii. (Photo: M. Andreev).

Acarospora williamsii Filson (1966). On rock and on compacted mineral soil at an altitude 910-960 m a. s. 1. Saxicolous and terricolous. Antarctic endemic. Occasional in continental Antarctic. Previously reported for DML (Schirmacher Oasis and internal areas). Collecting sites: Untersee $\mathbf{- 1 , 2 3}$; Obersee $\mathbf{- 3 7 .}$

Amandinea petermannii (Hue) Matzer, H. Mayrhofer \& Scheid. (1994). - [Syn.: Lecanora petermannii Hue; Rinodina petermannii (Hue) Darbishire; Beltaminia 
M. ANDREEV et al.

petermannii (Hue) C. W. Dodge; Rinodina convoluta D. C. Linds.]. In rock fissures in sheltered situations at an altitude $700-1100 \mathrm{~m}$ a. s. 1. Saxicolous. Antarctic endemic (Matzer et al. 1994). Widespread, common, and sometimes abundant on rocks near seashore and bird's nests in maritime Antarctic, but rare and little known in continental Antarctic, including the mentioned area. Previously reported and widely distributed throughout DML (Schirmacher Oasis and internal areas). Collecting sites: Untersee - 7, 12, 17, 19; Obersee - 34, 35, 37. Fig. 5C, 6B.

Buellia frigida Darb. (1910). On rock surfaces in exposed situations, along crevices or in cavities and in rock fissures at an altitude 750-1360 m a. s. 1. Saxicolous. Antarctic endemic. One of the most common and widespread lichens in the area and in continental Antarctic. Characteristic element of the Antarctic lichen flora. Previously reported and widely distributed throughout DML (Schirmacher Oasis and internal areas). Collecting sites - Untersee: 10, 12, 14, 16, 17, 18, 21, 23, 27, 28, 29, 30, 31, 39; Obersee - 35, 37. Fig. 5D.

Buellia pallida C. W. Dodge \& G. E. Baker (1938). - (Syn.: B. foecunda Filson). Collected in rock fissures at an altitude $960 \mathrm{~m}$ a. s. 1. Saxicolous. Antarctic endemic. Previously occasionally reported for DML (Schirmacher Oasis). Collecting sites: Untersee - 23.

Caloplaca citrina (Hoffm.) Th. Fr. (1860). - (Syn.: Pyrenodesmia mawsonii C. W. Dodge). On sandy soil, mosses and in rock fissures in sheltered habitats influenced by meltwater at an altitude 750-1370 m a. s. 1. Terricolous and saxicolous. Cosmopolitan bipolar. Widespread and common in continental Antarctic and in the area. Previously reported for DML (Schirmacher Oasis and internal areas). Caloplaca tominii, the species most similar to $C$. citrina, can easily be mistaken with the latter species, but differs in having simple, not incised thalline areoles and irregularly produced soralia from different parts of areoles. The thallus of $C$. citrina is usually completely dissolved into soredia or nearly so. Contrary to $C$. tominii, $C$. citrina while growing on the ground never occurs directly on soil, but overgrows mosses, plant debris or other lichens (Smykla et al. 2011). Collecting sites: Untersee - 11, 12, 17, 18, 21, 31; Obersee - 37. Fig. 6D.

Candelariella flava (C. W. Dodge \& G. E. Baker) Castello \& Nimis (1994). — [Syn.: Protoblastenia citrina C. W. Dodge; P. flava C. W. Dodge et G. E. Baker; P. hallettensis (J. S. Murray) C. W. Dodge; Candelariella hallettensis (J. S. Murray) Øvstedal; C. antarctica Filson; Lecidea hallettensis J. S. Murray]. On sandy soil and mosses in rock fissures in sheltered habitats and influenced by meltwater at an altitude 750-1360 m a. s. 1. Terricolous and muscicolous. Antarctic endemic. Widespread and common in continental Antarctic. Common but scanty in the area. Previously reported for DML (Schirmacher Oasis and internal areas). Collecting sites: Untersee - 6, 10, 11, 12, 17, 18, 28, 31; Obersee-37. Fig. 5E, 6D.

Endococcus propinquus (Körb.) D. Hawksw. (1979). - [Syn.: Discothecium gemmiferum (Tayl.) Vouaux]. Collected at an altitude $660 \mathrm{~m}$ a. s. 1. Lichenicolous fungus. Black spherical perithecia immersed in host tissue, appearing as minute black dots scattered over the thallus of Rusavskia elegans. Cosmopolitan bipolar. It is known from Subantarctic islands and the Antarctic Peninsula. Previously not reported for DML and continental Antarctic. Collecting sites: Untersee - $\mathbf{3 8}$. 

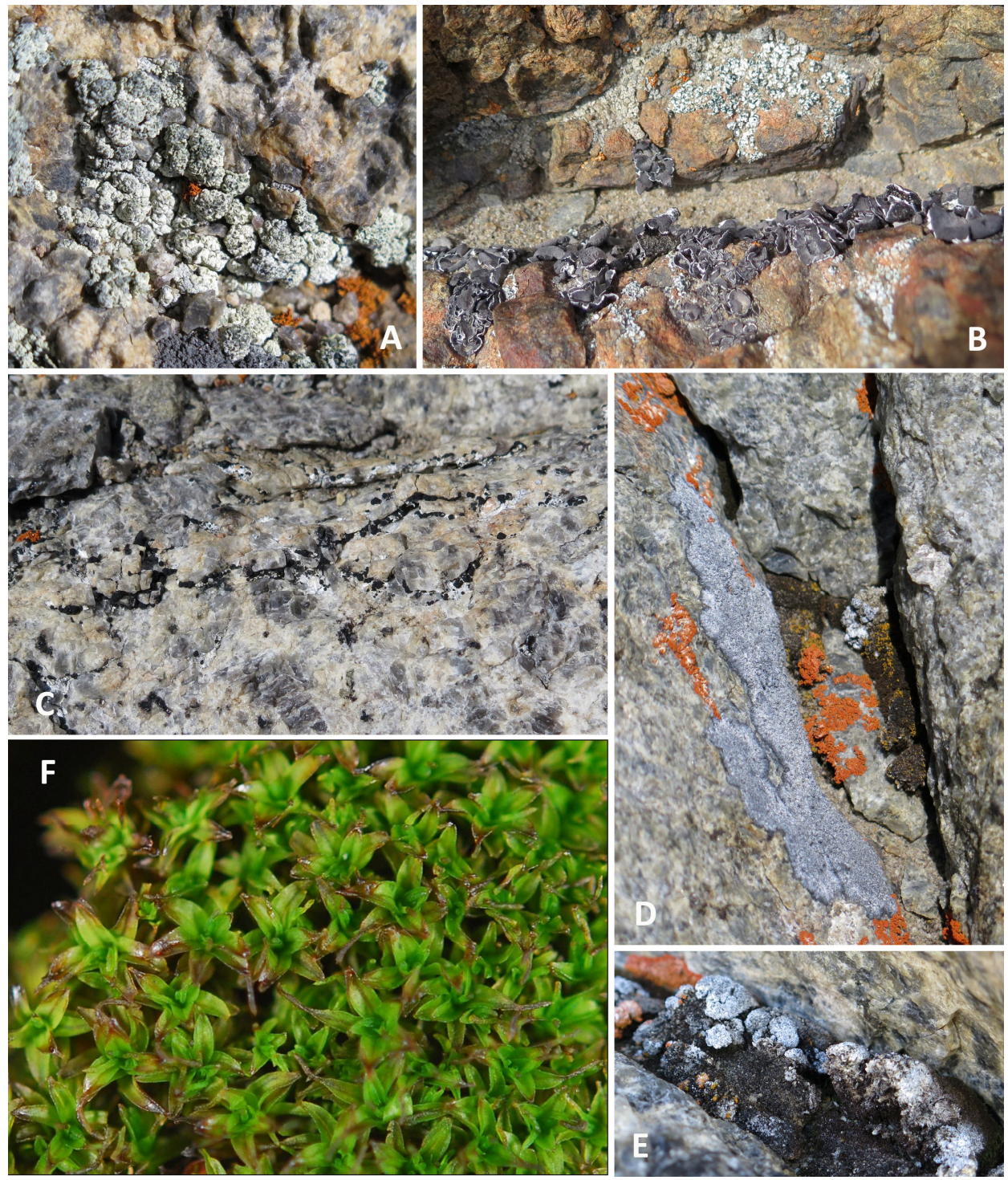

Fig. 6. Lichens and moss of the Lake Untersee Oasis. A - Rhizoplaca melanophthalma; B - Umbilicaria aprina \& Amandinea petermannii; C - Lecidella stigmatea; D - Syntrichia sacroneurum, Rusavskia elegans, Physcia dubia, Caloplaca citrina, Candelariella flava, Lecanora expectans; E - Lecanora expectans \& Syntrichia sacroneurum; F - Syntrichia sacroneurum. (Photo: M. Andreev - lichens, L. Kurbatova - Syntrichia sacroneurum).

Lecanora expectans Darb. (1910). - (Syn.: L. griseomarginata C. W. Dodge \& G. E. Baker). On mosses in sheltered places at an altitude of 750-1360 m a. s. 1., in habitats influenced by meltwater. Muscicolous. Antarctic endemic. Widespread and common in continental Antarctic. Occasionally found in the area. Previously reported and widely distributed throughout DML (Schirmacher Oasis and internal areas). Collecting sites: Untersee-1, 17, 18, 21, 28, 31. Fig. 6D, E. 
M. ANDREEV et al.

Lecanora mons-nivis Darb. (1912). Collected in rock fissure at an altitude $980 \mathrm{~m}$ a. s. 1. Saxicolous. Antarctic endemic. Occasionally found in continental Antarctic. Previously reported for DML (Schirmacher Oasis and internal areas). Collecting sites: Untersee-11.

Lecidea andersonii Filson (1975). In rock fissures and on exposed rocks at an altitude $750-950 \mathrm{~m}$ a. s. 1. Saxicolous. Antarctic endemic. Widespread and common in continental Antarctic and the area. Previously reported for DML (Schirmacher Oasis). Collecting sites: Untersee $-14,15,16,17,18,21$. Fig. 5F.

Lecidea cancriformis C. W. Dodge \& G. E. Baker (1938). - (Syn.: L. phillipsiana Filson). Collected in rock fissures at an altitude $760 \mathrm{~m}$ a. s. 1. Saxicolous. Antarctic endemic. Widespread and common in continental Antarctic. Previously reported for DML (Schirmacher Oasis and internal areas). Collecting sites: Untersee - 16.

Lecidella siplei (C. W. Dodge \& G. E. Baker) May. Inoue (1991). In rock fissures and on rock surfaces in protected places at an altitude $660-960 \mathrm{~m}$ a. s. 1. Spores $12-17 \times$ 8-10 $\mu \mathrm{m}$. Saxicolous. Antarctic endemic. Widespread and common in continental Antarctic and in the area. Previously reported for DML (Schirmacher Oasis and internal areas). Collecting sites: Untersee $\mathbf{- 2 3 , 3 8}$; Obersee $\mathbf{- 3 7}$.

Lecidella stigmatea (Ach.) Hertel \& Leuckert (1969). On exposed rocks and consolidated sand at an altitude 750-1020 m a. s. 1. Spores 15-18 $\times 8-10 \mu \mathrm{m}$. Saxicolous and terricolous. Bipolar. Widespread and common in continental Antarctic and in the area. Previously reported for DML (Schirmacher Oasis). Collecting sites: Untersee - 33, 39; Obersee-37. Fig. 6C.

Physcia caesia (Hoffm.) Fürnr. (1839). - (Syn.: Parmelia coreyi C. W. Dodge \& G. E. Baker; P. variolosa C. W. Dodge \& G. E. Baker; P. johnstonii C. W. Dodge). Collected on mosses in a sheltered place at an altitude $1260 \mathrm{~m}$ a. s. 1. Saxicolous and terricolous. Cosmopolitan bipolar. Widespread and common in continental Antarctic. Occasionally found in the area. Previously reported and widely distributed throughout DML (Schirmacher Oasis and internal areas). Collecting sites: Untersee - 28.

Physcia dubia (Hoffm.) Lettau (1912). - (Syn.: Parmelia leucoblephara C. W. Dodge \& G. E. Baker). On rocks and mosses in sheltered and moist places at an altitude 750 $910 \mathrm{~m}$ a. s. 1. Saxicolous and terricolous. Cosmopolitan bipolar. Widespread and common in continental Antarctic and the area. Previously reported and widely distributed throughout DML (Schirmacher Oasis and internal areas). Collecting sites: Untersee-17, 18; Obersee-37. Fig. 6D.

Pleopsidium chlorophanum (Wahlenb.) Zopf (1855). - (Syn.: Biatorella antarctica J. S. Murray; B. cerebriformis (C. W. Dodge) Filson; Acarospora chlorophana (Wahlenb.) A. Massal.; Candelariella cerebriformis (C. W. Dodge) Filson). In deep rock fissures in exposed and dry situations at an altitude 870-950 m a. s. 1. Saxicolous. Bipolar. Widespread and common in continental Antarctic and in the area, but always in small quantity. Previously reported for DML (Schirmacher Oasis and internal areas). Collecting sites: Untersee - 10, 14, U15.

Rhizoplaca macleanii (C. W. Dodge) Castello (2010). - (Syn.: Lecanora macleanii C. W. Dodge; Omphalodina macleanii (C. W. Dodge) C. W. Dodge). On rock surfaces in more sheltered situations on the altitude 910-1060 m a. s. 1. Saxicolous. Antarctic endemic. Widespread and common in continental Antarctic and in the area. New for DML Collecting sites: Untersee - 12, 21, 35; Obersee - 37. 
Rhizoplaca melanophthalma (Ram.) Leuckert \& Poelt (1977). - (Syn.: Lecanora melanophthalma (Ramond) Ramond; L. rubina Ach. var. melanophthalma (Ram.) Zahlbr., L. exulans (Th. Fr.) C. W. Dodge \& G. E. Baker;? L. fuscobrunnea C. W. Dodge $\&$ G. E. Baker). In rock fissures and on rocks surfaces in exposed situations at an altitude 870-1 $060 \mathrm{~m}$ a. s. 1. Saxicolous. Bipolar. Widespread and common in continental Antarctic and in the area. Previously reported and widely distributed throughout DML (Schirmacher Oasis and internal areas). Collecting sites: Untersee - 14, 21, 23, 35; Obersee-37. Fig. 5A, 6A.

Rusavskia elegans (Link) S. Y. Kondr. \& Kärnefelt (2003). — (Syn.: Xanthoria elegans (Link) Th. Fr.). In rock fissures and on consolidated debris in very exposed situations, mainly in habitats influenced by meltwater at an altitude $660-1360 \mathrm{~m}$ a. s. 1. Specimen 193801 is parasitized by a lichenicolous fungus Endococcus propinquus. Mainly saxicolous. Cosmopolitan bipolar. Widespread and common in continental Antarctic. The most common lichen in the area. Previously reported and widely distributed throughout DML (Lake Untersee Oasis, Obersee, 14.12.1983, HAL - F14 (Richter 1995); Schirmacher Oasis and internal areas). Collecting sites: Untersee - 11, 13, 14, 16, 17, 18, 21, 22, 23, 27, 28, 29, 30, 31, 38, 39; Obersee - 33, 37. Fig. 5D, 6D.

Sarcogyne privigna (Ach.) A. Massal. (1854). - (Syn.: S. angulosa C. W. Dodge \& G. E. Baker). Collected in rock fissure in exposed situation at an altitude $750 \mathrm{~m}$ a. s. 1 . Saxicolous. Cosmopolitan bipolar. Rather widespread and common in continental Antarctic. Occasionally found in the area. Previously reported for DML (Schirmacher Oasis). Collecting sites: Untersee - 17.

Umbilicaria antarctica Frey \& I. M. Lamb (1939). Collected on rock surface in protected place influenced by meltwater at an altitude $1260 \mathrm{~m}$ a. s. 1. Saxicolous. Antarctic endemic. Widespread and common in coastal continental Antarctic. Occasionally found in the area. Previously reported for DML (Schirmacher Oasis and internal areas). Collecting sites: Untersee - 28 .

Umbilicaria aprina Nyl. (1869). - (Syn.: U. antarctica Frey \& I. M. Lamb var. subvirginis Frey \& I. M. Lamb; Omphalodiscus spongiosus (C. W. Dodge \& G. E. Baker) Llano var. subvirginis (I. M. Lamb \& Frey) N. S. Golubk.; Umbilicaria saviczii Llano; U. korotkeviczii N. S. Golubk.). Collected on rock surface in sheltered places influenced by meltwater at an altitude $760-910 \mathrm{~m}$ a. s. 1. Saxicolous. Cosmopolitan bipolar. Widespread and common in continental Antarctic and in the area. Previously reported and widely distributed throughout DML (the Lake Untersee Oasis, Obersee, 14.12.1983, HAL - F13 (Richter 1995); Schirmacher Oasis and internal areas). Collecting sites: Untersee - 16; Obersee-37. Fig. 6B.

Xanthomendoza borealis (R. Sant. \& Poelt) Søchting, Kärnefelt \& S. Y. Kondr. (2002). - (Syn.: Xanthoria borealis R. Sant. \& Poelt, X. mawsonii auct. non C. W. Dodge). In rock fissures and on mosses in sheltered habitats influenced by meltwater at an altitude 910-1260 m a. s. 1. Saxicolous and muscicolous. Cosmopolitan bipolar. Widespread and common in continental Antarctic (Lindblom, Søchting 2008). A common lichen in the area. Previously reported and widely distributed throughout DML, in many cases as Xanthoria candellaria: (Schirmacher Oasis and internal areas). Collecting sites: Untersee-12, 21, 28; Obersee-37. 


\section{Bryophythes}

Syntrichia sacroneurum Ochyra \& R. H. Zander (2007). - [Syn.: Sarconeurum glaciale (Müll. Hall.) Card. \& Bryhn]. In vertical rock crevices and, lower down the slope on rocks sheltered from winds in wet habitats at an altitude 751-1255 m a. s. 1 . Rupicolous and epigean mosss. Antarctic endemic. Panantarctic species. Widespread and locally common in continental Antarctic, with two apparent major centers of occurrence in Dronning Maud Land and Victoria Land (Ochyra et al. 2008). The species was previously reported for DML (Schirmacher Oasis and internal areas). Collecting sites: Untersee-17, 18, 21, 28. Fig. 6D, E, F.

\section{Algae (Cyanoprokaryota, Cyanophyta, Cyanobacteria)}

Asterocapsa sp. 1. Cells $7-10 \mu \mathrm{m}$ diam., olive, mucilaginous sheaths black-violet. Collecting sites: Obersee-36. Fig. 7(A).

Asterocapsa sp. 2. Cells $6-8 \mu \mathrm{m}$ diam., olive, mucilaginous sheaths orange. (Komárek 2014). Collecting sites: Obersee - 36. Fig. 7(B).

Calothrix cf. elsteri Komárek. Filaments 100-230(500) $\mu \mathrm{m}$ long., 10-17 $\mu \mathrm{m}$ wide; sheath yellow-brown. Trichomes at the base 7-10(12) $\mu \mathrm{m}$ wide, cells $2.5-5 \mu \mathrm{m}$ long, at the apex 2-3 trichomes $\mu \mathrm{m}$ wide, cells 3-5 $\mu \mathrm{m}$ long. Heterocyts 5-11 $\mu \mathrm{m}$ long, 8-12 $\mu \mathrm{m}$ wide. Differs from the diagnosis (Komárek et al. 2012) by having wider trichomes (in original description $-5-7 \mu \mathrm{m}$ ) and its drier habitat (in original description - lakes and seepages). Collecting sites: Obersee - 36. Fig. 7(C).

Chlorogloea cf. antarctica Komárek. Cells $3.5 \mu \mathrm{m}$ diam., pink, mucilaginous sheaths yellow. Similar to Chlorogloea antarctica (Komárek 2014), but differs by the color of the cells (in original description - bright-blue-green) and drier habitat (in original description - seepages). Collecting sites: Obersee - 36. Fig. 7(E).

Chroococcidiopsis sp. Mother cells up to $12 \mu \mathrm{m}$ in diam., baeocytes $2-3 \mu \mathrm{m}$ in diam., bright-blue-green. Collecting sites: Untersee-21. Fig. 7(D).

Gloeocapsa cf. sanguinea (C. Agardh) Kützing. Cells 4-5(6) $\mu \mathrm{m}$ in diam., mucilaginous sheaths red. The identity of populations from temperate and tropical zones should be verified by molecular sequencing. Collecting sites: Obersee-36. Fig. 7(F).

Gloeocapsa cf. violacea Kützing. Cells $4-5 \mu \mathrm{m}$ in diam., mucilaginous sheaths blackviolet. The identity of populations from temperate and tropical zones should be verified by molecular sequencing. Collecting sites: Obersee - 36. Fig. 7(G).

Hassallia sp. Filaments 13-20 $\mu \mathrm{m}$ wide, trichomes 7.5-8 $\mu \mathrm{m}$ wide, cells $2.5-4 \mu \mathrm{m}$ long, heterocysts $6-8 \mu \mathrm{m}$ long, 7.5-8 $\mu \mathrm{m}$ wide, sheath yellow-brown. Similar to Hassallia sp. described from wet rocks on King George Island (Komárek et al. 2015). Collecting sites: Obersee - 36. Fig. 7(J).

Leptolyngbya antarctica (West \& G. S. West) Anagnostidis \& Komárek. Trichomes 0.5-0.6 $\mu \mathrm{m}$ wide, cells $1-1.2 \mu \mathrm{m}$ long. Previously reported from Dronning Maud Land: vicinity of Syowa station (Komárek 2007, Hirano 1979), vicinity of Novolazarevskaya station (Komárek, 2007). Previously reported in Antarctica: Larsemann Hills, Vestfold Hills, McMurdo Dry Valleys, Victoria Land (Cavacini et al. 2006), Bratina Island (Taton et al. 2006), James Ross Island (Komárek 2007). Collecting sites: Obersee - 36. 


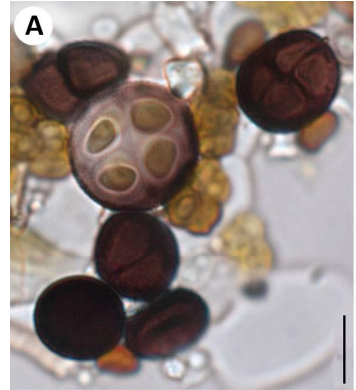

D

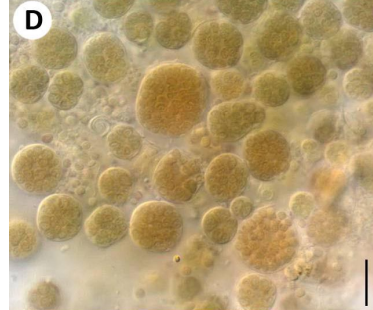

G
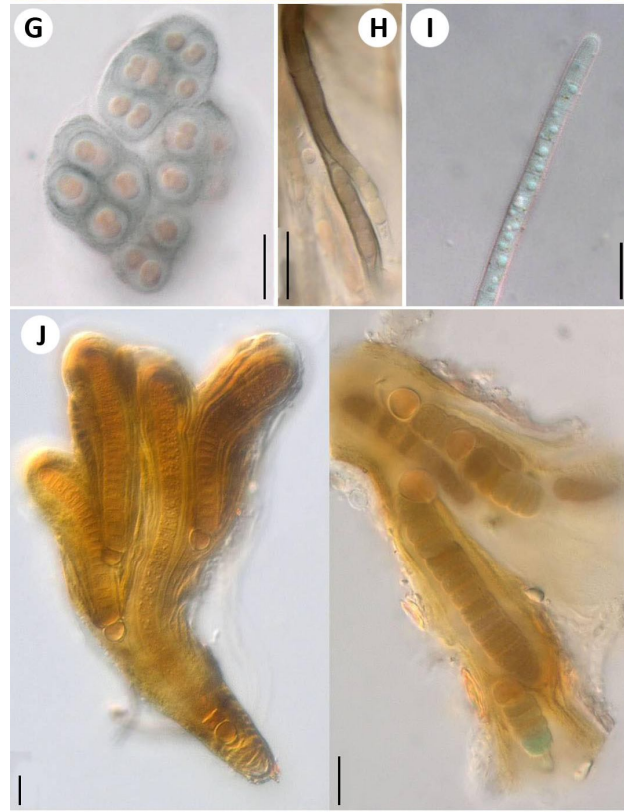
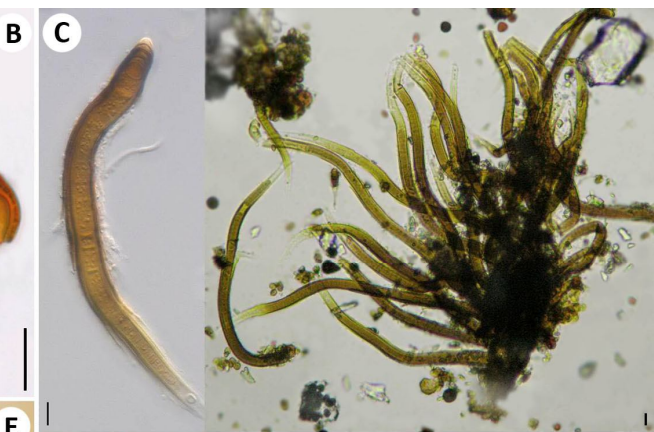

E

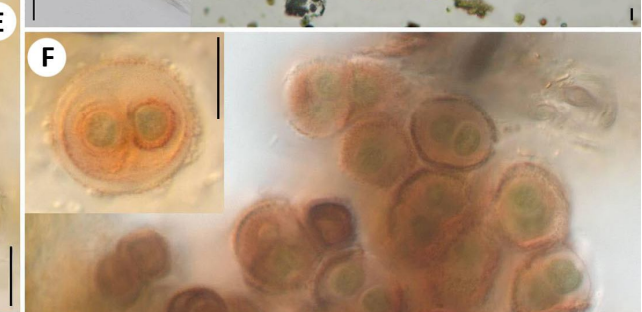

Fig. 7. Cyanoprokaryots of the Lake Untersee Oasis. A - Asterocapsa sp. 1; B - Asterocapsa sp. 2; C - Calothrix cf. elsteri; D - Chroococcidiopsis sp.; E - Chlorogloea cf. antarctica; $\mathrm{F}$ - Gloeocapsa $\mathrm{cf}$. sanguinea; $\mathrm{G}$ - Gloeocapsa $\mathrm{cf}$. violacea; $\mathrm{H}$ - Phormidesmis nigrescens; I - Wilmottia murrayi; J - Hassallia $\mathrm{sp}$.; K - Phormidesmis priestly. Scale bar - $10 \mu \mathrm{m}$. (Photo: S. Smirnova).

Leptolyngbya erebi (West \& G. S. West) Anagnostidis \& Komárek. Trichomes $0.7 \mu \mathrm{m}$ wide, cells 1.2-2.2 $\mu \mathrm{m}$ long. Previously reported in Antarctica: James Ross Island, King George Island (Komárek 2007). Collecting sites: Obersee - 36. 
M. ANDREEV et al.

Leptolyngbya frigida (F. E. Fritsch) Anagnostidis \& Komárek. Filaments $2.1 \mu \mathrm{m}$ wide, trichomes 1.8-1.9 $\mu \mathrm{m}$ wide, cells $1.5-2 \mu \mathrm{m}$ long. Previously reported in Antarctica: Larsemann Hills (Taton et al. 2006), Victoria Land (Cavacini et al. 2006). Collecting sites: Obersee $\mathbf{- 3 6}$.

Phormidesmis nigrescens (Komárek) Raabová, Kováčik, Elster \& Strunecký. Filaments 2.5-3.5 $\mu \mathrm{m}$ wide, trichomes 1.8-2 $\mu \mathrm{m}$ wide, cells $1.8-2.5 \mu \mathrm{m}$ long. Previously reported from Dronning Maud Land: Sør Rondane Mountains, Utsteinen Nunatak (FernandezCarazo et al. 2012). Previously reported in Antarctica: Larsemann Hills (Taton et al. 2006), James Ross Island, King George Island (Komárek 2007). Collecting sites: Obersee - 36. Fig. 7(H).

Phormidesmis priestleyi (F. E. Fritsch) Komárek, Kaštovský, Ventura, Turicchia \& Šmarda - (Syn.: Phormidium priestleyi F. E. Fritsch. Trichomes 1.9-2 $\mu$ m wide, cells 1.5-1.8 $\mu \mathrm{m}$ long. Previously reported from Dronning Maud Land: vicinity of Syowa station (Hirano 1979). Previously reported in Antarctica: Larsemann Hills (Taton et al. 2006), the McMurdo Dry Valleys (Fritsch 1917, Taton et al. 2006). Collecting sites: Untersee-21; Obersee-36. Fig. 7(K).

Wilmottia murrayi (West \& G. S. West) Strunecký, Elster \& Komárek. Filaments 6$6.5 \mu \mathrm{m}$ wide, trichomes 4-5 $\mu \mathrm{m}$ wide, cells 4-5 $\mu \mathrm{m}$ long. Previously reported from Dronning Maud Land: vicinity of Syowa station (Hirano 1979). Previously reported in Antarctica: McMurdo Ice Shelf (Nadeau et al. 2001, Casamatta et al. 2005, Strunecký et al. 2011), Vestfold Hills (Taton et al. 2006), Antarctic Peninsula, King George Island, James Ross Island, South Shetland Islands (Strunecký et al. 2011). Collecting sites: Obersee-36. Fig. 7(I).

\section{Algae (Chlorophyta)}

Prasiola crispa (Lightfoot) Kützing. Filamentous stage represented by uniseriate filaments, 14-18 $\mu \mathrm{m}$ wide. Cells disc-shaped, $0.2-0.5$ times as long as wide, containing a single axial chloroplast with a central pyrenoid. Cells in the plate 2.5-7 $\mu \mathrm{m}$ long and wide. In culture only filamentous stage occurs. Previously reported in Antarctica: South Orkney Islands, Signy Island (Broady 1979); South Shetland Islands, Deception Island (Fermani et al. 2007), Livingston Island (Zidarova 2008); Antarctic Peninsula, Cierva Point (Mataloni and Tell 2002, González Garraza et al. 2011); Vestfold Hills (Broady 1986); Ross Island (Broady 1989); Haswell Island (Kol 1968); Wilkes Land, Windmill Islands (Ling 1996); Victoria Land (Cavacini 2001). Collecting sites: Untersee - 26, 32. Fig. 8(C).

Prasionella wendyae Heesch, M. Pažoutová \& Rindi. Thalli consisting of small colonies up to $110 \mu \mathrm{m}$ in diam., sarcinoid, cushion-shaped or subglobular, containing a few to some hundreds of cells enclosed in a common envelope. Cells 3.5-8 $\mu \mathrm{m}$ long and wide (8-12 $\mu \mathrm{m}$ long, 4-6 $\mu \mathrm{m}$ wide in small colonies), containing a single axial chloroplast with a central pyrenoid. Reproduction by cell division and aplanospores. Reported for the first time for Antarctic region. Collecting sites: Untersee - 26. Fig. 8(A).

Stichococcus bacillaris Nägeli - (Syn.: Stichococcus nivalis Chodat). Filaments easily broken. Cells single or connected in 2-4, sometimes curved, cylindrical, often rounded at the ends, 3-6 $\mu \mathrm{m}$ wide, 4-10 $\mu \mathrm{m}$ long. Chloroplast parietal, not dissected, occupying most of the cell. Previously reported in Antarctica: South Orkney Islands, Signy 
Island (Broady 1979); South Shetland Islands, Deception Island (Fermani et al. 2007), Livingston Island (Zidarova 2008); Antarctic Peninsula, Cierva Point (González Garraza et al. 2011), Hope Bay (Bonaventura et al. 2006); Balleny Islands (Kol and Flint 1968); Haswell Island (Kol 1968); Wilkes Land, Windmill Islands (Ling 1996); Victoria Land (Cavacini 2001). Collecting sites: Untersee - 17, U26. Fig. 8(B).

Trebouxia cf. arboricola Puym. Cells single or in small clusters, globular, mature to 15$20 \mu \mathrm{m}$ in diameter. Cell wall up to $1 \mu \mathrm{m}$ thick. Chloroplast axial, in young cells saucershaped, in mature massive, randomly and weakly lobed at the edge. Pyrenoid one, mostly in the center, no starch involucre. Aplanospores, 4-16 linger in the parent cell wall, and after release for some time, remaining together. Precise identification is difficult because it was not possible to trace the formation of zoospores. Trebouxia spp. were recorded on the Antarctic Peninsula, Cierva Point (González Garraza et al. 2011); in Prince Charles Mts., Clemence Massif (Andreeva and Kurbatova 2014). Collecting sites: Untersee - 17. Fig. 8(D).

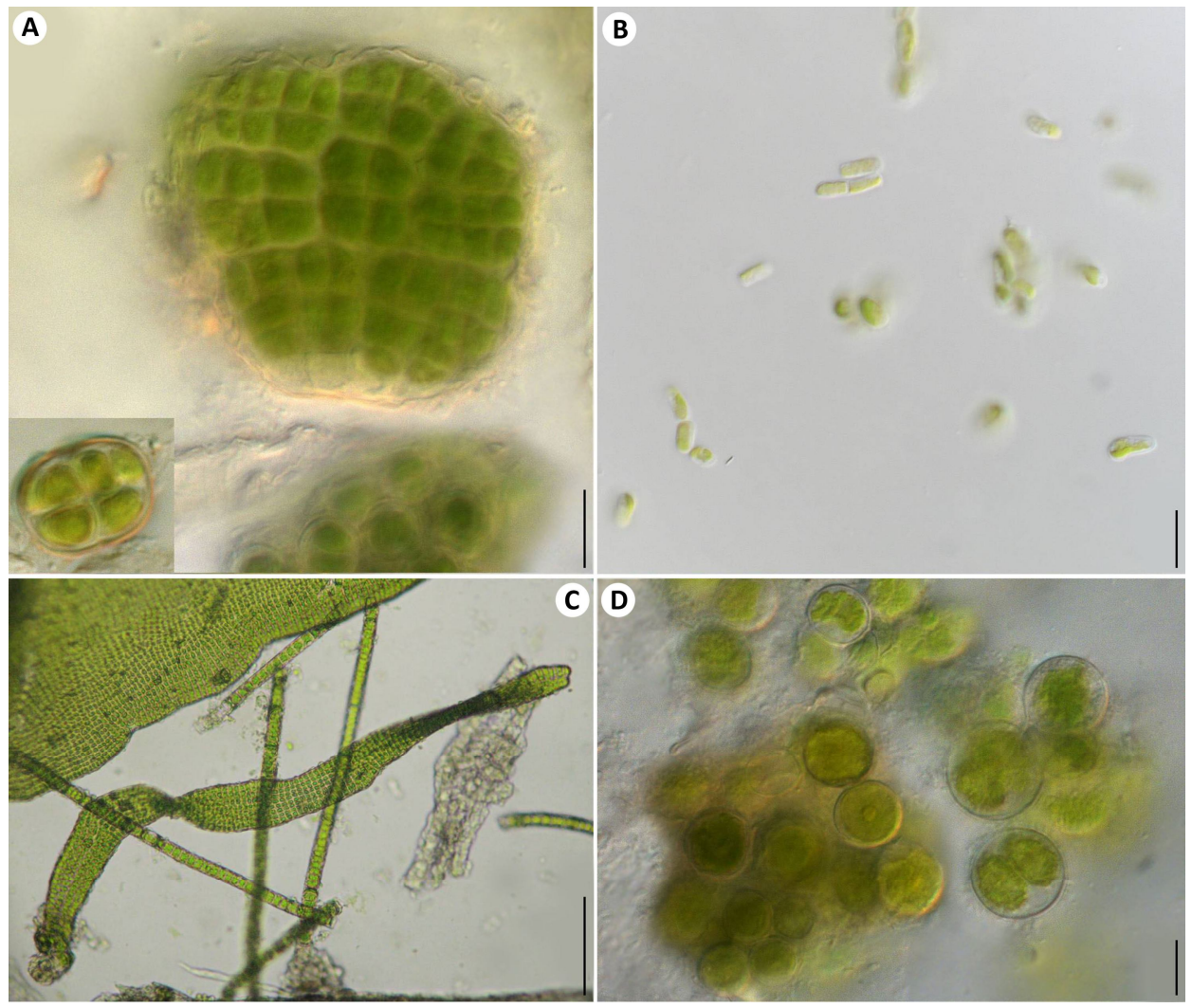

Fig. 8. Green algae of the Lake Untersee Oasis. A - Prasionella wendyae; B - Stichococcus bacillaris; C - Prasiola crispa; D - Trebouxia cf. arboricola; Scale bar - $10 \mu \mathrm{m}$ (A, B, D); $100 \mu \mathrm{m}$ (C). (Photo: S. Smirnova). 
M. ANDREEV et al.

\section{References}

AleshinskayA, Z. V., BARDin, V. I. (1965): Diatom flora in the Schirmacher Oasis. Informatsionnyi Byulleten' Sovetskoi Antarkticheskoi Ekspeditsii [Newsletter of the Soviet Antarctic Expedition], 54: 47-49. (In Russian).

Andersen, D. T., Sumner, D. Y., Hawes, I., Webster-Brown, J. and Mckay, C. P. (2011): Discovery of large conical stromatolites in Lake Untersee, Antarctica. Geobiology, 9: 280-293.

Andersen, D. T., McKay, C. P. and Lagun, V. (2015): Climate conditions at perennially icecovered lake Untersee, East Antarctica. Journal of Applied Meteorology and Climatology, 54: 1393-1412.

Andreeva, V. M., Kurbatova, L. E. (2014): Terrestrial and aerophilic nonmotile green microalgae (Chlorophyta) from regions of investigation of Russian Antarctic expedition. Novosti Sistematiki Nizshikh Rastenii [Novitates systematicae plantarum non vascularium], 48: 12-26. (In Russian).

Bonaventura, S. M., Vinocur, A., Allende, L. and Pizarro, H. (2006): Algal structure of the littoral epilithon in lentic water bodies at Hope Bay, Antarctic Peninsula. Polar Biology, 29(8): 668-680.

Bormann, P., Fritzsche, D. (eds.) (1995): The Schirmacher Oasis, Queen Maud Land, East Antarctica, and its surroundings. Justus Perthes Verlag, Gotha, Germany, $448 \mathrm{p}$.

Bowra, G. T., Holdgate, M. W. and Tilbrook, P. J. (1966): Biological investigations in Tottanfjella and Central Heimefrotfjella. British Antarctic Survey Bulletin, 9: 63-70.

Broady, P. A. (1979): The terrestrial algae of Signy Island, South Orkney Islands. British Antarctic Survey Scientific Reports, 98, 117 p.

BROADY, P. A. (1986): Ecology and taxonomy of the terrestrial algae of the Vestfold Hills. In: J. Pickard (ed.): Antarctic Oasis. Terrestrial environments and history of the Vestfold Hills. Academic Press, London, pp. 165-202.

BROADY, P. A. (1989): Broadscale patterns in the distribution of aquatic and terrestrial vegetation at three ice-free regions on Ross Island, Antarctica. Hydrobiologia, 172(1): 7-95.

Brown, R. M., Bold, H. C. (1964): Phycological studies. 5. Comparative studies of the algal genera Tetracystis and Chlorococcum. University of Texas Publication, 6417: $213 \mathrm{pp}$.

Casamatta, D. A., Johansen, J. R., Vis, M. L. and Broadwater, S. T. (2005): Molecular and morphological characterization of ten polar and near-polar strains within the Oscillatoriales (Cyanobacteria). Journal of Phycology, 41: 421-438.

CAVACINI, P. (2001): Soil algae from northern Victoria Land (Antarctica). Polar Bioscience, 14: 45-60.

Cavacini, P., Tagliaventi, N. and Fumanti, B. (2006): Morphology, ecology and distribution of an endemic Antarctic lacustrine diatom: Chamaepinnularia cymatopleura comb. nov. Diatom Research, 21(1): 57-70.

Dodge, C. W. (1962): Expédition antarctique Belge. Lichens. Bulletin du Jardin botanique de l'État a Bruxelles, 32: 301-308.

ENGELSKJøn, T. (1985): Botany of Gjelsvikfjella and Mühlig-Hofmannfjella, Dronning Maud Land - with some contributions from H. U. Sverdrupfjella and Vestfjella. Rep. NARE 1984/85. Norsk Polarinstifutt Rapport, 22: 43-54.

ENGELSKJøN, T. (1986): Botany of two Antarctic mountain ranges: Gjelsvikfjella and MühligHofmannfjella, Dronning Maud Land. I. General ecology and development of the Antarctic cold desert cryptogam formation. Polar Research, 4(2): 205-224.

Ertz, D., Aptroot, A., Van De Vijver, B., Moermans, C. and Øvstedal, D. (2014): Lichens from the Utsteinen Nunatak (Sør Rondane Mountains, Antarctica), with the description of one new species and the establishment of permanent plots. Phytotaxa, 191(1): 99-114.

Fermani, P., Mataloni, G. and VAn De ViJVer, B. (2007): Soil microalgae communities on an Antarctic active volcano (Deception Island, South Shetlands). Polar Biology, 30(11): 13811393. 
Fernandez-Carazo, R., Namsaraev, Z., Mano, M.-J., Ertz, D. and Wilmotte, A. (2012): Cyanobacterial diversity for an anthropogenic impact assessment in the Sør Rondane Mountains area, Antarctica. Antarctic Science, 24(3): 229-242.

FritsCh, F. E. (1917): Freshwater algae. In: British Antarctic (Terra Nova) Expedition, 1910. Natural History Report, pp. 1-17.

Golubkova, N. S., SAvicz, V. P. (1965): Species familiae Acarosporaceae e parte orientali Antarctidis. Novosti Sistematiki Nizshikh Rastenii [Novitates systematicae plantarum non vascularium], 2: 173-178.

Golubkova, N. S., SAvicz, V. P. (1966): Lichenes familiae Umbilicariaceae e parte orientali Antarctidae. Novosti Sistematiki Nizshikh Rastenii [Novitates systematicae plantarum non vascularium], 3: 257-263.

GolubKova, N. S., Simonov, I. M. (1972): The lichens of the Schirmacher Oasis. Trudy Sovetskoy Antarkticheskoy Ekspeditsii [Transactions of the Soviet Antarctic Expedition], 60: 317-327. (In Russian).

González Garraza, G., Mataloni, G., Fermani, P. and Vinocur, A. (2011): Ecology of algal communities of different soil types from Cierva Point, Antarctic Peninsula. Polar Biology, 34(3): 339-351.

Gupta, B. K., SinHa, G. P. and Singh, D. K. (1999): A note on lichens of Schirmacher Oasis, East Antarctica. Indian Journal of Forestry, 22: 292-294.

HAENDEL, D., KAUP, E. (1986): Hydrochemische Untersuchungen im Unterseegebiet im Zentralen Wohlthatmassiv, Ostantarktika. Geodatische und geophysikalische Veröffentlichungen, 13: 7292.

Heesch, S., Pažoutová, M., Moniz Monica, B. J. and Rindi, F. (2016): Prasiolales (Trebouxiophyceae, Chlorophyta) of the Svalbard Archipelago: diversity, biogeography and description of the new genera Prasionella and Prasionema. European Journal of Phycology, 51 (2): 171-187.

HeRmichen, W. D., KowsKi, P. and WAND, U. (1985): Lake Untersee, a first isotope study of the largest freshwater lake in the interior of East Antarctica. Nature, 315: 131-133.

Hirano, M. (1979): Freshwater algae from Yukidori Zawa, near Syowa Station, Antarctica. Memoris of the National Institute of Polar Research, Special Issue 11: 1-25.

HuneCK, S., Richter, W. (1982): The ecology and chemistry of some Antarctic lichens. Isotopes in Antarctic Research - Contribution of the GDR. ZFI-Mitteilungen, 51: 111-120.

Kaup, E., Loopmann, A., Klokov, V., Simonov, I. and Haendel, D. (1988): Limnological investigations in the Untersee Oasis, Queen Maud Land, East Antarctica. In: J. Martin (ed.): Limnological studies in Queen Maud Land, East Antarctica. Valgus, Tallinn, pp. 28-42.

KLOKOv, V. D., Simonov, I. M., KAup, E. V. and LoOpmAnN, A. A. (1987): Sudies of the mountain lakes in Untersee oasis. Informatsionnyi Byulleten' Sovetskoi Antarkticheskoi Ekspeditsii [Newsletter of the Soviet Antarctic Expedition], 109: 45-50. (In Russian).

Kol, E. (1968): Algae from the Antarctica. Annales Historico-Naturales Musei Nationalis Hungarici Pars Botanica, 60: 71-76.

Kol, E., Flint, E. A. (1968): Algae in green ice from Balleny islands, Antarctica. New Zealand Journal of Botany, 6(3): 249-261.

KomÁREK, J. (2007): Phenotype diversity of the cyanobacterial genus Leptolyngbya in the maritime Antarctic. Polish Polar Research, 28(3): 211-231.

KomÁReK, J. (2014): Phenotypic and ecological diversity of freshwater coccoid cyanobacteria from maritime Antarctica and Islands of NW Weddell Sea. II. Czech Polar Reports, 4(1): 1739.

Komárek, J., NedbalovÁ, L. and Hauer, T. (2012): Phylogenetic position and taxonomy of three heterocytous cyanobacteria dominating the littoral of deglaciated lakes, James Ross Island, Antarctica. Polar Biology, 35: 759-774.

KomÁreK, J., GenuÁrio, D. B., Fiore, M. F. and Elster, J. (2015): Heterocytous cyanobacteria of the Ulu Peninsula, James Ross Island, Antarctica. Polar Biology, 38: 475-492. 
M. ANDREEV et al.

Kosenko, N. G., Kolobov, D. D. (1970): Exploration of the Lake Untersee. Informatsionnyi Byulleten' Sovetskoi Antarkticheskoi Ekspeditsii [Newsletter of the Soviet Antarctic Expedition], 79: 65-69. (In Russian).

Kurbatova, L. E., Ochyra, R. (2012): Two noteworthy additions to the moss flora of the Schirmacher Oasis in the continental Antarctic. Cryptogamie, Bryologie, 33(2): 159-167.

LAL, J. (2004): Bryophytes of Schirmacher Oasis. Nineteenth Indian expedition to Antarctica, scientific report. Department of Ocean Development Technical Publication, 17: 165-171.

Lindblom, L., Søchting, U. (2008): Taxonomic revision of Xanthomendoza borealis and Xanthoria mawsonii (Lecanoromycetes, Ascomycota). Lichenologist, 40: 399-409.

LindSAY, D. C. (1971): Notes on Antarctic lichens: IV. Lichens from Tottanfjella, Dronning Maud Land. British Antarctic Survey Bulletin, 25: 99-100.

Lindsay, D. C. (1972): Lichens from Vestfjella, Dronning Maud Land. Norsk Polarinstitutt Meddelelser, 101: 1-21.

Lindsay, D. C., BRoOK, D. (1971): Lichens from the Theron Mountains. British Antarctic Survey Bulletin, 25: 95-98.

LING, H. U. (1996): Snow algae of the Windmill Island region, Antarctica. Hydrobiologia, 336(1): 99-106.

Mataloni, G., Tell, G. (2002): Microalgal communities from ornithogenic soils at Cierva Point, Antarctic Peninsula. Polar Biology, 25(7): 488-491.

Matzer, M., Mayrhofer, H. and Scheidegger, C. (1994): Notes on Amandinea petermannii comb. nov. (Physciaceae) from Antarctica. Lichenologist, 26: 39-46.

Nadeau, T.-L., Milbrandt, E. C. and Castenholz, R. W. (2001): Evolutionary relationships of cultivated Antarctic oscillatorians (Cyanobacteria). Journal of Phycology, 37: 650-654.

NAYAKA, S., UpReTI, D. K. (2005): Schirmacher Oasis, East Antarctica, a lichenologically interesting region. Current science, 89(7): 1069-1071.

NAYAKA, S., UPRETI, D. K. (2008): Distribution and diversity of lichens in Schirmacher Oasis and neighboring nunataks, East Antarctica. Twenty second Indian expedition to Antarctica. Scientific report. Technical publication, 20: 227-241.

NAYAKA, S., UPRETI, D. K. and BAJPAI, R. (2009): Diversity and adaptive response of lichens in Antarctica. In: K. R. Sridhar (ed.): Frontiers in fungal ecology, diversity and metabolites. New Delhi, pp. 107-123.

Ochyra, R., Lewis Smith, R. I. and Bednarek-Ochyra, H. (2008): The illustrated moss flora of Antarctica. Cambridge University Press, Cambridge, UK, 685 p.

OchYRA, R., Singh, S. M. (2008): Three remarkable moss records from Dronning Maud Land, continental Antarctica. Nova Hedwigia, 86: 497-506.

Ohyama, Y., Higashi, S., Miyawaki, H., Hiruta, S., Kanda, S. and Kanda, H. (1991): Biological surveys in the Sør Rondane Mountains, Dronning Maud Land, in 1989 and 1990 seasons. Nankyoku Shiryô [Antarctic Record], 35(2): 238-246.

Olech, M., Singh, S. M. (2010): Lichens and lichenicolous fungi of Schirmacher Oasis, Antarctica. National Centre for Antarctic and Ocean Research. NISCAIR, New Delhi, India, $140 \mathrm{p}$.

Øvstedal, D. O. (1983a): Some lichens from H. U. Sverdrup Mountains, Dronning Maud land, Antarctis. Nova Hedwigia, 37: 683-690.

Øvstedal, D. O. (1983b): Some lichens from Vestfjella, Dronning Maud Land, Antarctis. Crypotgamie, Bryologie et Lichénologie, 4: 217-226.

Øvstedal, D. O. (1986): Lichens and lichen parasites from the British Swedish Norwegian Antarctic expedition 1949-1952 to Dronning Maud Land. Cryptogamie, Bryologie, Lichénologie, 7: 63-70.

PANDEY, V., UpRETI, D. K. (2000): Lichen flora of Schirmacher Oasis and Vettiyya Nunatak. Scientific Report Seventeenth Indian Expedition to Antarctica. Technical Publication, 15: 185201.

RichTER, W. (1985): Laub- und Strauchflechten im Gebiet der Schirmacher-Oase (Systematik, Verbreitung, Ökologie, I). Geodatische und geophysikalische Veröffentlichungen, 12: 95-102. 
RichteR, W. (1986): Häufige und auffällige Krustenflechten in der Schirmacheroase: Catillaria cremea, Acarospora gwynii, Rhizocarpon flavum und Buellia frigida (Flechten der Schirmacheroase, III). Geodatische und geophysikalische Veröffentlichungen, 13: 122-131.

Richter, W. (1990): The lichens of the Schirmacher Oasis (East Antarctica). Geodatische und geophysikalische Veröffentlichungen, 16: 471-488.

RichTER, W. (1995): Lichen flora. In: P. Bormann, D. Fritzsche (eds.): The Schirmacher Oasis, Queen Maud Land, East Antarctica and its surroundings. Justus Perthes Verlag, Gotha, Germany, pp. 321-347.

Richter, W., Bormann, P. (1995): Hydrology. In: P. Bormann, D. Fritzsche (eds.): The Schirmacher Oasis, Queen Maud Land, East Antarctica and its surroundings. Justus Perthes Verlag, Gotha, Germany, pp. 259-320.

Ryan, P. G., Watkins, B. P., Lewis Smith, R. I., Dastych, H., Eicker, A., Foissner, W., Heatwole, H., Miller, W. R. and Thompson, G. (1989): Biological survey of Robertskollen, western Dronning Maud Land: area description and preliminary species list. South African Journal of Antarctic Research, 19(1): 10-20.

SAVicz-Lyubitskaya, L. I., Smirnova, Z. N. (1964): A deep-water member of the genus Plagiothecium Br. et Sch. in Antarctica. Informatsionnyi Byulleten' Sovetskoi Antarkticheskoi Ekspeditsii [Newsletter of the Soviet Antarctic Expedition], 49: 33-39. (In Russian).

Simonov, I. M., Stackebrandt, W., Haendel, D., Kaup, E., KämpF, H. and Loopmann, A. (1985): Komplexe naturwissenschaftliche Untersuchungen am Unter- und Obersee, Zentrales Dronning-Maud-Land, Antarktika. Petermanns Geographische Mitteilungen, 129: 125-135.

Smykla, J., Krzewicka, B., Wilk, K., Emslie, S. D. and Sliwa, L. (2011): Additions to the lichen flora of Victoria Land, Antarctica. Polish Polar Research, 32(2): 123-138.

STACKEBRANDT, W. (1995): Moraines around Lake Untersee - indicators of the Late-Quaternary regional glacial history. In: P. Bormann, D. Fritzsche (eds.): The Schirmacher Oasis, Queen Maud Land, East Antarctica and its surroundings. Justus Perthes Verlag, Gotha, Germany, pp. $237-242$

StruneckÝ, O., Elster, J. and KomÁReK, J. (2011): Taxonomic revision of the freshwater cyanobacterium "Phormidium" murrayi $=$ Wilmottia murrayi. Fottea, 11: 57-71.

Taton, A., Grubisic, S., Ertz, D., Hodgson, D. A., Piccardi, R., Biondi, N., Tredici, M. R., Mainini, M., Losi, D., Marinelli, F. and Wilmotte, A. (2006): Polyphasic study of Antarctic cyanobacterial strains. Journal of Phycology, 42: 1257-1270.

THOR, G. (1995): Reassessment of the first lichen and moss collections from Heimefrontfjella, Dronning Maud Land. Antarctic Science, 7: 261-264.

UPRETI, D. K. (1996): Lecideoid lichens from the Schirmacher Oasis, East Antarctica. Willdenowia, 25: 681-686.

UpRETI, D. K. (1997): Notes on some crustose lichens from Schirmacher Oasis, East Antarctica. Feddes Repertorium, 108: 281-286.

WAND, U., Schwarz, G., BrügGemann, E. and BräUer, K. (1997): Evidence for physical and chemical stratification in Lake Untersee (central Dronning Maud Land, East Antarctica). Antarctic Science, 9: 43-45.

ZidarovA, R. P. (2008): Algae from Livingston Island (S. Shetland Islands): A checklist. Phytologia Balcanica. 14(1): 19-35.

\section{Web sources / Other sources}

[1] Map Wohlthatmassivet, Fimbulheimen, Sheet M5. Norsk Polarinstitutt, Oslo, 1968.

[2] Atlas Antarktiki (1969): Vol. 2. Gidrometeoisdat, Leningrad, USSR, 598 p. (In Russian). 